\title{
Using iPad to Facilitate English Vocabulary Learning
}

\author{
B. T. Wang, C. W. Teng, and H. T. Chen
}

\begin{abstract}
With the development of new technologies, such as Web pages, Apps or social network, the language learning environment seems to be more multiple and interesting. The aim of this paper is to use iPad App in a Taiwanese classroom to help students' English vocabulary acquisition. During the 18-week lecture, the instructor chose two freshman English classes with a total of 74 students in a private university in Taiwan to be the research subjects. The classes were divided into 2 groups, that is, the experimental group and the control group. In the experimental group, the instructor used iPad "Learn British English WordPower App" to teach English vocabulary while the instructor used the traditional semantic-map method to teach English vocabulary in the control group. The vocabulary teaching lasted about 15 minutes each time, and students under the iPad instruction were able to see the words, word pictures and example sentences through the classroom projector. Besides, class one was asked to fill out the questionnaire to understand students' attitude toward iPad App teaching in the classroom. The results showed that at the end of the semester, students who received the iPad vocabulary teaching instruction performed better on the post-test. Also, the survey found out that students agreed on using technologies in the classroom can help language learning. That is, using iPad Apps in language teaching can not only enhances students' learning outcomes, but also increases students' learning motivation.
\end{abstract}

Index Terms —English vocabulary acquisition, iPad, learning outcomes, learning motivation, semantic-map method.

\section{INTRODUCTION}

Vocabulary is the foundation of English language learning [1], [2]. Having enough vocabulary can make communication more smooth and precise so that people can convey ideas and enhance their listening, speaking, reading and writing skills [3], [4]. However, many English learners feel confused when they learn vocabulary because there are always new words in the articles. In addition, the learners fail to find appropriate words to express themselves. The worst of all, it seems like mission impossible for them to memorize the vocabulary no matter how much time they spend on reciting the words [5]. Is there another way for everyone to learn English vocabulary happily?

There are a lot of methods to learn English vocabulary, such as using flashcards, taking notes, learning through affix, and so on [6], [7]. There are also some teachers and learners use the techniques of collocations, association or extensive reading [8]. No matter which method is being used, it is

Manuscript received January 13, 2014; revised March 13, 2014.

Bor-Tyng Wang and Han-Tung Chen are with the Foreign Language Center, Feng-Chia University, Taiwan (e-mail: btwang.tw@gmail.com, vivianchensbs@yahoo.com).

Chun-Wen Teng is with Gradute Institute of Public Policy, Feng-Chia University, Taiwan (e-mail: cwteng@fcuoa.fcu.edu.tw). important to reach the study goal first and then learners can find their best vocabulary learning strategies.

In this paper, we focused on using the iPad App - "Learn British English WordPower" to freshman students in a Taiwanese classroom. We tried to investigate whether there is a difference in students' English vocabulary acquisition performances under different teaching instructions (iPad and semantic-map method).

According to the relevant researches, using the information and communication technologies (ICT) can not only increase students' learning motivation, but also enhance the interaction features in the classroom [9], [10]. That is, ICT have a great impact on the teaching and learning process in the $21^{\text {st }}$ century. For ICT can influence the way students are taught and their performances by providing wider access and different interaction to the content [9]-[11].

Therefore, the instructor used the iPad App and semantic-map method in two freshman English classes, respectively. The teaching of vocabulary lasted about 15 minutes each time. Students took the same English pre-test at the beginning of the semester and the English post-test at the end of the semester. In addition, a questionnaire of using iPad App in the classroom was conducted in the class with iPad instruction at the end of the semester.

Based on the above reasons, the paper examines the following questions:

1) Does the iPad App enhance significant progress in students' English vocabulary acquisition?

2) Based on students' attitude and needs, can ICT teaching in the classroom increase their learning motivation?

\section{LITERATURE REVIEW}

\section{A. Computer-Assisted Language Learning}

Using ICT in the classroom is a new method of teaching technique which provides more interaction, and makes students' learning more effectively [12]. During the teaching activities, the ICT have been applied to various aspects of pedagogies. In English teaching fields, this kind of computer-assisted language learning can support and extend English curriculum goals which make students engage in meaningful English learning activities, enhance their English communication skills and increase their reading and writing abilities [12], [13].

In addition, the use of computers in language teaching also guarantees to develop students' cooperation skill, communication skill, problem-solving skill and life-long learning ability [12]. In the past, English teaching in Taiwan focused on grammar and neglected to teach English listening and speaking skills. This resulted in students' low learning motivation and poor communication skills. If the English teaching methods can be modified into a lively and 
interactive model, students' interest in learning English should have been enhanced [14].

Some researchers think that integrating technology into the curriculum is one of the tools being used in the classroom, which can help students solve their problems, have in-depth knowledge to the professional field and train higher level of learning outcomes [15], [16]. By using the computer in teaching, students can learn critical thinking and construct their knowledge system to reach higher-order learning [17].

Hence, integrating technology in English teaching can reach the following goals: train students' information literacy, inspire students' learning motivation and interests, enhance the effectiveness of learning English, increase students' communication skills, make students understand different culture, and strengthen students' self-explosion and life-long learning ability [18].

\section{B. English Vocabulary Teaching Methods}

There are many English vocabulary teaching strategies, such as word family, compound words, collocation, semantic map, affix, context clue, etc. [19]. In this paper, the method of semantic map is used, and here is a brief introduction of this method. There are two main purposes for teachers to use semantic map in vocabulary teaching [20]:

1) Enable students to understand the specific content of the concept of the word.

2) Increase students' vocabulary by using relevant words or examples.

For example, when teacher teaches clothes, students can come up with the relevant words like jeans, shorts, sweater, jacket, T-shirt, pajamas, etc. Then students can draw the semantic map on the blackboard. Please see Fig. 1 as an example.

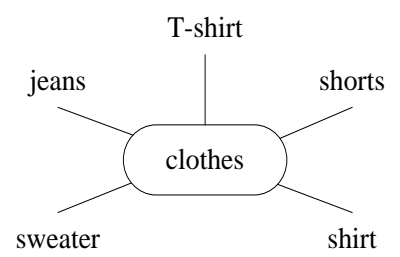

Fig. 1. An example of semantic map.

\section{RESEARCH DESIGN}

\section{A. Participants}

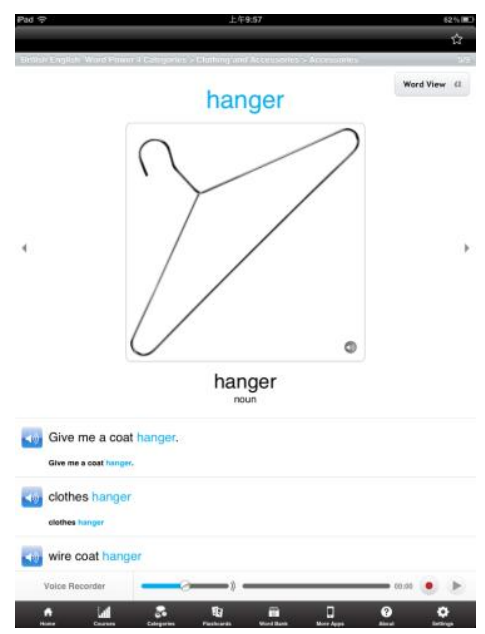

Fig. 2. Example one of iPad App.
The instructor chose two freshman English classes in a private university in Taiwan as the research subjects. There were 36 and 38 students in each class. All of the students were in the same English level (basic level, equivalent to CEF A2) based on their placement test results. Class one, with 36 students, was chosen as the experimental group which learned English vocabulary through iPad "Learn British English WordPower App (See Fig. 2 and Fig. 3)." Class two, with 38 students, was chosen as the control group that learned the English vocabulary through the semantic-map method.

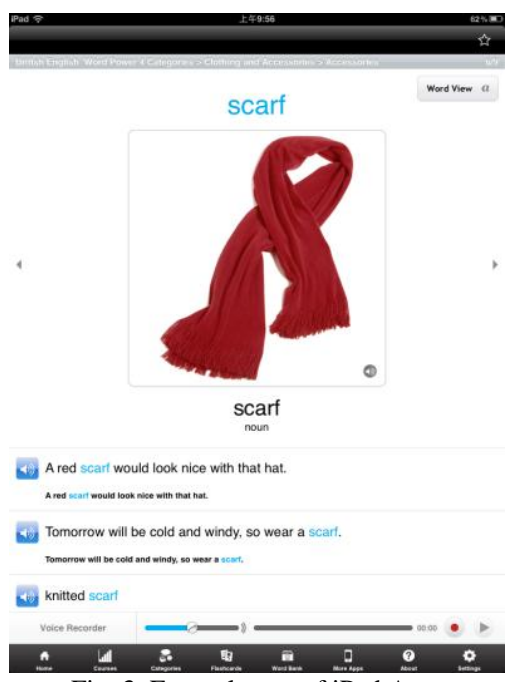

Fig. 3. Example one of iPad App.

\section{B. Procedure}

According to the school schedule, there are 18 weeks per semester. After deducting the school holidays, mid-term and final exams, there are about 14 lectures left. Hence, the instructor used two different methods, the iPad App and semantic-map method, to teach English vocabulary in two freshman English classes. Then both of the two classes took the same English pre-test and English post-test, which was administrated at the end of the course to check the students' progress. The research flowchart is shown in Fig. 4 as follows.

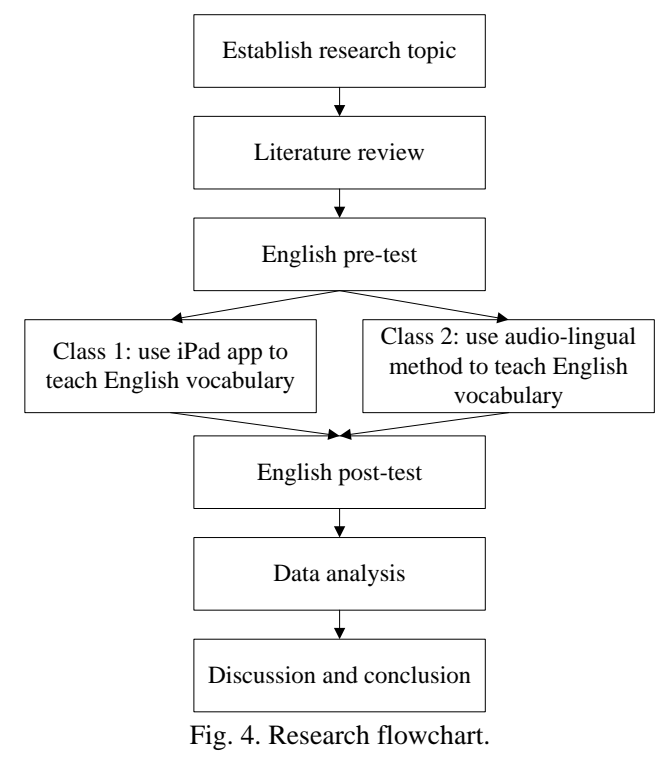

In addition, the experimental group was asked to fill out 
the questionnaire of using iPad App teaching in the classroom and the questionnaire, including 8 items, is shown in Table I.

TABLE I: USING IPAD APP IN THE CLASSROOM

\begin{tabular}{|c|c|}
\hline Questions & Content \\
\hline Q1 & $\begin{array}{l}\text { Through iPad App instruction, I like English } \\
\text { better. }\end{array}$ \\
\hline Q2 & $\begin{array}{l}\text { Through iPad App instruction, I feel more } \\
\text { confident in learning English vocabulary. } \\
\text { Through iPad App instruction, I am willing }\end{array}$ \\
\hline Q3 & $\begin{array}{l}\text { to spend more time learning English } \\
\text { vocabulary. }\end{array}$ \\
\hline Q4 & $\begin{array}{l}\text { To me, the use of iPad teaching makes me } \\
\text { understand the English vocabulary better } \\
\text { than the use of blackboard. }\end{array}$ \\
\hline Q5 & $\begin{array}{l}\text { The use of iPad App in the classroom can't } \\
\text { increase my learning motivation. }\end{array}$ \\
\hline Q6 & $\begin{array}{l}\text { After school, I want to download the iPad } \\
\text { App and review the vocabulary. }\end{array}$ \\
\hline Q7 & $\begin{array}{l}\text { As a whole, I have high evaluation on the } \\
\text { use of iPad App in the classroom. }\end{array}$ \\
\hline Q8 & $\begin{array}{l}\text { In the future, I am willing to try other } \\
\text { different technology tools, like Youtube, } \\
\text { computer games or Blog, in English } \\
\text { language learning. }\end{array}$ \\
\hline
\end{tabular}

A five-point Likert-scale is used to indicate students' statement by choosing among the five responses ranging from "strongly disagree to strongly agree." The data collection was limited to the experimental group $(N=36)$.

\section{Instrument}

In order to check whether the two different methods make any difference on students' English vocabulary acquisition, SPSS 12.0 was used to see if there was a statistically significant difference in two classes' pre-test and post-test scores. An independent samples t-test was used for comparing the means on variable between two teaching methods.

The iPad App-Learn British English WordPower was used in the experimental group (see Fig. 2 and Fig. 3). This App has approximately 2000 words and phrases which show the spelling, translation, pronunciation, and image.

Besides, descriptive statistics was used to analyze the questionnaire of using iPad App teaching in the classroom. The frequency percentages, means and SD were reported.

\section{RESULTS AND DISCUSSION}

\section{A. Students' Pre-Test Results}

Based on Table II, the $p$ value is higher than .05 , and this showed that there was no significant difference with experimental group and control group at the beginning of the research.

TABLE II: THE INDEPENDENT SAMPLE T-TEST OF ENGLISH PRE-TEST

\begin{tabular}{lcccl}
\hline \hline & Number & Mean & $\begin{array}{l}\text { Std } \\
\text { Deviation }\end{array}$ & $\begin{array}{l}\text { Sig } \\
\text { (2-tailed) }\end{array}$ \\
\hline $\begin{array}{l}\text { Experimental } \\
\text { group }\end{array}$ & 36 & 62.12 & 10.85 & .070 \\
Control group & 38 & 60.16 & 12.79 & .070 \\
\hline \hline
\end{tabular}

\section{B. Students' Post-Test Results}

According to the results in Table III, there was a significant difference in the scores between experimental group $(M=68.9, S D=6.7)$ and control group $(M=62.0$, $S D=9.0)$. That is, the use of iPad App in English vocabulary teaching has positive effect on students' performance and helps students in English vocabulary acquisition. Under the iPad App instruction, the experimental group performed better in the post-test and made a big progress.

TABLE III: THE INDEPENDENT SAMPLE T-TEST OF ENGLISH POST-TEST

\begin{tabular}{lccll}
\hline \hline & Number & Mean & $\begin{array}{l}\text { Std } \\
\text { Deviation }\end{array}$ & $\begin{array}{l}\text { Sig } \\
\text { (2-tailed) }\end{array}$ \\
\hline $\begin{array}{l}\text { Experimental } \\
\text { group }\end{array}$ & 36 & 68.9 & 6.74 & .000 \\
\begin{tabular}{l} 
Control group \\
\hline \hline
\end{tabular} & 38 & 62.0 & 9.08 & .000 \\
\hline
\end{tabular}

\section{Questionnaire Analysis}

The results of descriptive analysis of the questionnaire (percentages, means and SD) were shown in Table IV. The main purpose of the questionnaire was to understand students' attitude toward ICT use in the classroom. Moreover, this questionnaire was only distributed in the experimental group.

TABLE IV: PERCENTAGES, MEANS AND STANDARD DEVIATION OF USING IPAD APP IN THE CLASSROOM

\begin{tabular}{llllllll}
\hline \multirow{2}{*}{ Items } & \multicolumn{2}{c}{ Percent $(\%)$} & & \multicolumn{3}{c}{ Mean } & SD \\
\cline { 1 - 4 } & SA & A & N & D & SD & & \\
\hline Q1 & 42.86 & 42.86 & 14.29 & 0 & 0 & 4.29 & 0.20 \\
Q2 & 42.31 & 30.77 & 23.08 & 0 & 3.85 & 4.08 & 1.02 \\
Q3 & 50 & 46.15 & 3.85 & 0 & 0 & 4.46 & 0.58 \\
Q4 & 57.69 & 38.46 & 3.85 & 0 & 0 & 4.54 & 0.58 \\
Q5 & 7.69 & 3.85 & 34.62 & 15.38 & 38.46 & 2.26 & 0.70 \\
Q6 & 46.67 & 40 & 13.33 & 0 & 0 & 4.33 & 0.71 \\
Q7 & 60 & 33.33 & 6.67 & 0 & 0 & 4.53 & 0.63 \\
Q8 & 50 & 43.33 & 6.67 & 0 & 0 & 4.43 & 0.63 \\
\hline \hline
\end{tabular}

For question one, $42.86 \%$ of the students showed that they liked English better through iPad App instruction whereas $0 \%$ of them denied this statement. Next, for the confidence in English vocabulary learning, there were more than $2 / 3$ of the students stated that they felt more confident whereas only $3.85 \%$ of them reported that they were still lack of confidence. Among the 8 questions, question 2 scored the lowest mean of 4.08. It might be the Chinese culture because students are shy and humble. Question 3 asked students whether they would spend more time on learning English vocabulary after experienced iPad App instructions in the classroom. The result of question 3 was very positive because there were $96.15 \%$ of the students agreed on this item. The analysis of students' understanding of English vocabulary showed that they agreed that the use iPad App was better than the traditional blackboard lecture (mean=4.54). With regard to the only negative item in this questionnaire, question 5 aimed to understand if students' learning motivation had increased. The results were quite interesting because half of the students disagreed on item 5 whereas $34.62 \%$ of the students were neutral and $11.54 \%$ of them agreed on this item. Question 6 
wanted to test students' self-study attitude by asking if they would download the App and reviewed the lessons. The results showed that $86.67 \%$ of the students would do this after class whereas $13.33 \%$ of them were neutral. Question 7 aimed to know the overall attitude among students toward the use of iPad teaching in the classroom, and the result scored the highest "strongly agree" of all the 8 items. That is, there were about $93.33 \%$ of the students had high evaluation on the use of iPad App in the classroom. The final question wanted to know if students wanted to try other ICT tools in the future. The results turned out to be good due to nobody disagreed on this item and there were approximately $93.33 \%$ of the students wanted to continue to use the ICT tools in the future.

\section{Discussion}

The findings of this paper are summarized as follows:

1) The iPad App created significant progress in students' English vocabulary acquisition.

The current research tended to understand students' progress and attitude in English vocabulary acquisition under the iPad teaching. The findings in this paper showed very positive results. First of all, the experimental group, who learned English vocabulary through the iPad instruction, performed better in the English post-test than the control group. Table III showed that the final exam average score of the experimental group $(M=68.9)$ was higher than that of the control group $(M=62)$. The independent sample t-test showed that there was a significant difference between the experimental group and the control group $(p=.000<.05)$. This also proved that the proposed teaching method (using iPad in the classroom) is effective.

2) Using ICT teaching in the classroom had positive effects on students' English learning motivation.

Another major finding in this paper was that students' learning motivation was increased in the ICT classroom. The research explored students' attitude toward the use of ICT in the classroom. According to items 3, 5 and 6 in the questionnaire, students were more active for English vocabulary learning. Moreover, based on item 1 and item 2, students' attitude toward English was changed, and there were more students who wanted to learn English.

3) The use of iPad teaching created a relaxed learning environment.

In English vocabulary teaching, the effectiveness of vocabulary acquisition depends on the method the teacher uses and teacher's enthusiasm [21]. Since the development of English vocabulary acquisition is a long-term work, the learning should not be limited to in-class lectures. Instead, teachers should encourage students to develop self-study habits and increase students' learning motivation. By using the ICT, students will feel familiar and relaxed in the classroom. In this paper, the use of iPad App in English vocabulary teaching provided lots of pictures, words, sentences, audio-files and pronunciation practices in the traditional classroom. It was totally different from the traditional teacher-centered lecture. With the use of iPad, there were more interactions between the teacher and students, and students seemed to be more focused during the lectures. According to the researches, the visual effects provided by the ICT really help the increase in students' learning motivation [12], [13]. The results of this paper were corresponded with these previous researches. Hence, the iPad App provided a meaningful learning interface in the traditional Taiwanese classroom. Instead of memorizing the word by word, students got more chances to think and apply the words. Also, the learning responsibility has been transferred from teacher to students. Moreover, students can download the App after class and review the lessons at any time, any place. It is like seamless learning and if the teacher can use this kind of ICT tools in the classroom, it can be beneficial for both teachers and students.

4) The ICT teaching had influenced students' willingness of using computers in English learning.

Based on the results of the questionnaire, students wanted to try different ICT in future study. After the instructor used the iPad App to teach English vocabulary in the classroom, students seemed to understand how to apply the ICT in learning and this is in line with the previous research findings [17], [18].

\section{CONCLUSION AND IMPLICATION}

According to the research results, the instructor believes that using iPad in English teaching has positive effect on students and the results were as follows:

1) The effectiveness of using iPad in students' English vocabulary acquisition had been approved.

After using iPad app-“Learn British English WordPower" in English vocabulary teaching (see Fig. 2 \& Fig. 3), the experimental group showed a great performance on the post-test than the control group. Hence, it is believed that applying ICT method in English teaching has its positive effectiveness.

2) Students' attitude toward ICT in the classroom was positive.

According to the results of the questionnaire, the experimental group felt motivated, delighted and interested in using iPad App to learn English vocabulary.

3) The teachers are encouraged to use more ICT applications in the classroom in the future.

Based on item 10 in the questionnaire, students are willing to learn English by using different ICTs. Therefore, teachers need to realize this trend and apply more ICTs in English language teaching in the future not only to meet students' needs, but also to create a lively learning environment.

However, the number of students in this paper limits the reliability of the results. If there can be more classes and students involving in this research, and teachers' attitude can also be investigated, the reliability and validity of this paper can be increased. In the future, it is also suggested to include interviews of teachers and students to enhance the completeness of the research.

\section{REFERENCES}

[1] B. T. Wang, T. W. Sheu, H. T. Chen, M. McCollister, and H. Y. Chang, "Using technology for improving English skills: Learning English is fun with Youtube," in Proc. 2012 CALL Conference, Taiwan, 2012, pp. 612-615.

[2] J. Yun, "The effects of hypertext glosses on L2 vocabulary acquisition: A meta-analysis," Computer Assisted Language Learning, vol. 24, no. 1, pp. 39-58, 2011. 
[3] N. Schmitt, Vocabulary in Language Teaching, Cambridge: Cambridge University Press, 2000.

[4] I. S. P. Nation, Learning Vocabulary in Another Language, Cambridge: Cambridge University Press, 2001.

[5] A. Cervatiuc, "ESL vocabulary acquisition: Target and approach," The Internet TESL Journal, vol. 14, no. 1, January 2008.

[6] S. Rott, J. Williams, and R. Cameron, "The effect of multiple-choice L1 glosses and input-output cycles on lexical acquisition and retention," Language Teaching Research, vol. 6, no. 3, pp. 183-222, 2002.

[7] A. M. Shapiro and D. L. Waters, "An investigation of the cognitive processes underlying the keyword method of foreign vocabulary learning," Language Teaching Research, vol. 9, no. 2, pp. 129-146, 2005.

[8] A. Asgari and G. B. Mustapha, "The type of vocabulary learning strategies used by ESL students in university of Putra Malaysia," English Language Teaching, vol. 4, no. 2, pp. 84-90, June 2011.

[9] C. P. Lim and C. S. Chai, "An activity-theoretical approach to research of ICT integration in Singapore schools: orienting activities and learner autonomy," Computers \& Education, vol. 43, no. 3, pp. 215-236, 2004

[10] T. Mooij, "'Design of educational and ICT conditions to integrate differences in learning: contextual learning theory and a first transformation step in early education," Computers in Human Behaviour, vol. 23, no. 3, pp. 1499-1530, 2007.

[11] S. Harris, "Innovative pedagogical practices using ICT in schools in England," Journal of Computer Assisted Learning, no. 18, pp. 449-458, 2002.

[12] M. Drent and M. Meelissen, "Which factors obstruct or stimulate teacher educators to use ICT innovatively," Computers \& Education, vol. 51, pp. 187-199, 2008.

[13] D. S. Niederhauser and T. Stoddart, "Teachers' instructional perspectives and use of educational software," Teaching and Teacher Education, vol. 17, pp. 15-31, 2001.

[14] J. Adamson, "Investigating college student attitudes towards learning English and their learning strategies: Insights from interviews in Thailand," Journal of Asia TEFL, vol. 1, no. 5, pp. 47-70, 2004.

[15] J. Harris, "Our agenda for technology integration: It's time to choose," Contemporary Issues in Technology and Teacher Education, vol. 5, no. 2, pp. 116-122, 2005.

[16] R. McCormick and P. Scrimshaw, "Information and communications technology, knowledge, and pedagogy," Education, Communication and Information, vol. 1, no. 1, pp. 37-57, 2001.

[17] D. H. Jonassen, C. Carr, and H. P. Yueh, "Computers as mindtools for engaging learners in critical thinking," TechTrends, vol. 43, no. 2, pp. 24-32, March 1998.
[18] C. Pope and J. Golub, "Preparing tomorrow's English language arts teachers today: Principles and practices for infusing technology," Contemporary Issues in Technology and Teacher Education, vol. 1, no. 1, pp. 89-97, 2000.

[19] C. L. Z. Blachowicz and P. Fisher, Teaching Vocabulary in All Classrooms, Columbus, OH: Pearson Merrill-Prentice Hall, 2006.

[20] A. Sokmen, "Current trends in teaching second language vocabulary," in Vocabulary: Description, Acquisition and Pedagogy, N. Schmitt \& M. Michael, Ed., Cambridge: Cambridge University Press, 1997, pp. 237-257.

[21] I. S. P. Nation, Teaching and Learning Vocabulary, Boston: Heinle \& Heinle, 1990.

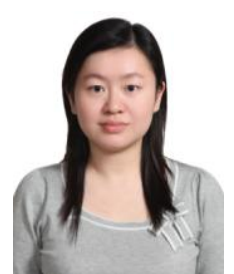

Bor-Tyng Wang is currently an assistant professor of Foreign Language Center at Feng-Chia University, Taiwan. She received her Ph.D. degree in Graduate Institute of Educational Measurement and Statistics from National Taichung University of Education, Taiwan. Her research interests include dynamic assessment, knowledge structure analysis, English language teaching and CALL. She was also the associate executive editor of International Journal of Kansei Information.

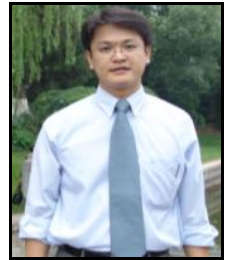

Chun-Wen Teng is currently an assistant professor of Graduate Institute of Public Policy at Feng-Chia University, Taiwan. He received his Ph.D. degree in Department of Education from National Chengchi University, Taiwan. He research interests include higher education, curriculum and instruction design and e-learning. He is also the executive officer of Center for Teaching and Learning Resource at Feng-Chia University.

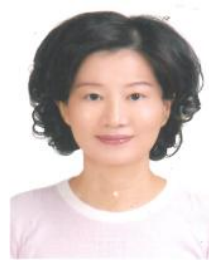

Han-Tung Chen is currently a lecturer of Foreign Language Center at Feng-Chia University, Taiwan. She received her master's degree of TESOL from UCLA, the U.S. Her research interests include English language teaching, CALL and e-learning. She has written some books related to the fields of business English, extensive readers and general English. 